\begin{tabular}{|c|c|}
\hline \multirow{3}{*}{ 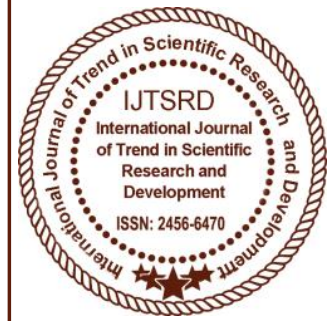 } & $\begin{array}{l}\text { International Journal of Trend in Scientific } \\
\text { Research and Development (IJTSRD) }\end{array}$ \\
\hline & UGC Approved International Open Access Journal \\
\hline & ISSN No: 2456 - 6470 | www.ijtsrd.com | Volume - 1 | Issue - 5 \\
\hline
\end{tabular}

\title{
Study on Economic Development by Adoption of Recommended Groundnut Production Technology among the Farmers of Sehore District of M.P, India
}

\author{
Ms. Versha Patel \\ M.Sc. Students 2017, College of \\ Agriculture, Indore
}

\author{
Dr. Sandhya Choudhary \\ Associate Professor, College of \\ Agriculture, Indore
}

\author{
Dr. Abhay Wankhede \\ Assistant Professor, College of \\ Agriculture, Indore
}

\section{ABSTRACT}

Oilseeds are the second most important and the largest agri-commodity of India after cereals. Oilseed crops play a very important role in the agricultural economy of India which has the distinction of having large area under oilseed crops. The diverse agro-ecological conditions in the country are favourable for growing nine annual oilseeds which include seven edible oilseeds viz. groundnut, rapeseed mustard, soybean, sunflower, sesame, safflower and niger and two nonedible oilseeds, castor and linseed. The present study was conducted in Ashta block of Sehore district of Madhya Pradesh during 2016-17. 10 villages were selected randomly and 160 farmers were selected by using proportionate allocation method. The result of study indicated that among all respondents, 60.00 per cent had medium market behaviour, maximum number of the respondents $(33.75 \%)$ had small area, $10 \%$ of respondents had their annual income above Rs.1.00 lakh. Positively \& significantly related with adoption level of the farmers.

\section{INTRODUCTION}

In India, among the major oilseed growing states, the highest yield in 2014-15 of oilseed crops was recorded by Tamil Nadu ( $2479 \mathrm{~kg} / \mathrm{ha}$ ) followed by Gujarat (1608 kg/ha) and Haryana (1394 kg/ha). Similarly, states which are having lower yield levels of oilseed crops are Odisha (661 kg/ha), Assam (557 $\mathrm{kg} / \mathrm{ha})$, Chhattisgarh (550 kg/ha) and Madhya Pradesh (387 kg/ha).

Among the different oilseed crops, groundnut is one of the most excellent sources of high quality protein and edible oil and can play an important role in meeting the requirement of both protein and edible oil.

Groundnut, 'the unpredictable legume' is also known as peanut, earthnut, and monkey nut and manila nut. It is the 6th most important oilseed crop and 13th most important food crops of the world. The botanical name Arachis hypogaea L. has been derived from the Greek words, Arachis meaning a legume and hypogaea meaning below ground referring to geocarpic nature of pod formation. It is an important food, feed, and oilseed crop. 
Table- State-wise area, production and yield of groundnut in 2013-14

\begin{tabular}{|c|c|c|c|c|}
\hline S.N. & State & $\begin{array}{c}\text { Area } \\
\text { (Lakh ha) } \\
\end{array}$ & $\begin{array}{c}\text { Production } \\
\text { (Lakh tonnes) }\end{array}$ & $\begin{array}{c}\text { Yield } \\
\text { (kg/ha) }\end{array}$ \\
\hline 1. & Andhra Pradesh & 13.86 & 12.34 & 890 \\
\hline 2. & Gujarat & 18.42 & 49.18 & 2670 \\
\hline 3. & Karnataka & 7.25 & 6.58 & 908 \\
\hline 4. & Madhya Pradesh & 2.00 & 1.98 & 990 \\
\hline 5. & Maharashtra & 2.67 & 3.25 & 1217 \\
\hline 6. & Odisha & 0.58 & 0.8 & 1379 \\
\hline 7. & Rajasthan & 4.66 & 9.06 & 1944 \\
\hline 8. & Tamil Nadu & 3.42 & 9.62 & 2813 \\
\hline 9. & Uttar Pradesh & 0.96 & 0.86 & 896 \\
\hline 10. & West Bengal & 0.79 & 2.02 & 2557 \\
\hline \multicolumn{2}{|r|}{ Others } & 0.66 & 1.04 & 1576 \\
\hline \multicolumn{2}{|r|}{ All India } & 55.27 & 96.73 & 1750 \\
\hline
\end{tabular}

Source: Directorate of Economics and Statistics, Department of Agriculture and Cooperation

A research had therefore been planned to study' Study on economic development by adoption of recommended groundnut production technology among the farmers of Sehore district of M.P, India

\section{Objective}

To see the impact of extent of adoption of recommended groundnut production technology by the farmers on their economic status

\section{Review of Literature}

\section{Area of Groundnut}

Kumar (2011) found that maximum number of the respondents $(41.67 \%)$ had large size of land holding (above $4 \mathrm{ha}$ ), followed by 25.00 per cent respondents who belonged to small size of land holding (1 to 2 ha), whereas 17.50 per cent of the respondents were having medium size of land holding (2.1 to 4 ha) however only 15.83 per cent respondents belonged under marginal category (less than $1 \mathrm{ha}$ ).

Reddy and Shenoy (2013) observed that majority of groundnut farmers were average land holding (2-5 acres).

\section{Annual Income}

Mugisha et al. (2004) concluded that non- adopters of groundnut production technology earned more income annually compared to adopters.

Kumar (2011) found that majority $(73.33 \%)$ of the respondents were having their annual income between Rs.50000 to Rs.200000 followed by 15.00 per cent of respondents who were having their annual income below Rs 50000. Whereas, 11.67 percent of respondents were having their annual income above Rs 2 lacs.

\section{Marketing Behaviour}

Shukla and Gupta (2011) the marketing behaviour of growers in Jaipur and outlines the constraints they face in production and marketing. (based on data collected from 120 farmers during 2006-07)

Jyothi and Anand (2013) revealed that majority of FLD farmers fully adopted recommended technologies in groundnut cultivation. Whereas, majority of non-FLD farmers adopted the practices like land preparation, seed rate, season and intercultural operations, while, majority of them not used rhizobium, PSB and gypsum.

\section{Material \& Method}

The present study was conducted in Ashta block of Sehore district of Madhya Pradesh during 2016-17. 10 villages were selected randomly and 160 farmers were 
selected by using proportionate allocation method. The study was conducted with objectives to measure the knowledge and extent of adoption of farmers about recommended groundnut production technology in adoption of production technology. One hundred and sixty farmers were selected as the sample for study. The data was collected by personal interview with the help of structured schedule.

\section{Dependent Variable}

\section{Extent of Adoption of recommended groundnut production technology by the farmers}

It is mental process through which an individual passes from hearing about an innovation to final adoption (Rogers, 1995).

It was operationalized as the degree of the use of recommended practices. Adoption refers to the extent of use of recommended farming practices of groundnut cultivation by farmers. To measure the extent of adoption of recommended groundnut production technology an interview schedule was prepared with 16 questions.

\section{Independent variables}

\section{1-Area of groundnut}

It refers to the number of hectare land possessed by the farmer:

\begin{tabular}{|c|c|c|c|}
\hline $\begin{array}{c}\text { Sr. } \\
\text { No. }\end{array}$ & Category & Land holding & $\begin{array}{c}\text { Score } \\
\text { assigned }\end{array}$ \\
\hline $\mathbf{1}$ & Marginal & Up to 1 ha. & 1 \\
\hline $\mathbf{2}$ & Small & 1.01 to 2 ha. & 2 \\
\hline $\mathbf{3}$ & Medium & 2.01 to 4 ha. & 3 \\
\hline $\mathbf{4}$ & Large & 4.01 ha and above & 4 \\
\hline
\end{tabular}

\section{2-Annual Income}

Annual income of respondent refers to the total sum amount received by all the sources in the year. It is generally considered a primary measure of a nation's financial prosperity. On the basis of data collected, the respondents were classified into following three categories:

\begin{tabular}{|c|c|c|c|}
\hline $\begin{array}{c}\text { Sr. } \\
\text { No. }\end{array}$ & Category & Income & $\begin{array}{c}\text { Score } \\
\text { assigned }\end{array}$ \\
\hline 1. & Low income & $\begin{array}{c}\text { ( Up to Rs 50,000/- } \\
\text { ) }\end{array}$ & 1 \\
\hline 2. & $\begin{array}{c}\text { Medium } \\
\text { income }\end{array}$ & $\begin{array}{c}\text { (Rs. 50,001 to } \\
1,00,000 /-)\end{array}$ & 2 \\
\hline 3. & High income & $\begin{array}{c}\text { (Above Rs. } \\
1,00,000)\end{array}$ & 3 \\
\hline
\end{tabular}

\section{3- Marketing behaviour}

The data regarding the marketing behaviour were collected from the respondents on 3 point continuum scale namely least, medium and high proportion, the score was given in order 1,2 and 3 , respectively.

\begin{tabular}{|c|c|c|}
\hline Sr. No. & Proportion & Score assigned \\
\hline 1. & Least & 1 \\
\hline 2. & Medium & 2 \\
\hline 3. & High & 3 \\
\hline
\end{tabular}

\section{Result \& Discussion}

\section{1-Area of groundnut}

It refers to number of hectares of land owned and operated by the farmers. It largely determines the socio-economic status of family and source of livelihood. The data of the present investigation in this regard have been presented in Table 4.4.

\section{Table - Distribution of the respondents according to their area of groundnut}

\begin{tabular}{|c|c|c|c|c|}
\hline $\begin{array}{l}\text { Sr. } \\
\text { No. }\end{array}$ & Category & $\begin{array}{l}\text { Area of } \\
\text { groundnut }\end{array}$ & Frequency & Percentage \\
\hline 1. & Marginal & Up to 1 ha. & 29 & 18.13 \\
\hline 2. & Small & $\begin{array}{c}1.01 \text { to } 2 \\
\text { ha. }\end{array}$ & 54 & 33.75 \\
\hline 3. & Medium & $\begin{array}{c}2.01 \text { to } 4 \\
\text { ha. }\end{array}$ & 44 & 27.50 \\
\hline 4. & Large & $\begin{array}{c}4.01 \text { ha and } \\
\text { above }\end{array}$ & 33 & 20.62 \\
\hline \multicolumn{3}{|c|}{ Total } & 160 & 100 \\
\hline
\end{tabular}

It is apparent from the Table 4.4 that the maximum number of the respondents $(33.75 \%)$ had small area (1.1 to $2 \mathrm{ha}$ ), followed by 27.50 per cent respondents who belonged to medium area of land holding, whereas 20.62 per cent of the respondents were 
International Journal of Trend in Scientific Research and Development (IJTSRD) ISSN: 2456-6470

having large area of groundnut and only 18.13 per cent respondents belonged under marginal area category. It could be concluded that maximum number of respondents belonged to small area of groundnut category.

\section{2-Annual income}

Annual income of farm family refers to the total sum amount received by all the sources in the year. It describes the economic condition of human beings. Categorization of annual income as low, medium and high has been given as below:

\section{Table - Distribution of respondents according to their annual income}

\begin{tabular}{|c|c|c|c|}
\hline $\begin{array}{c}\text { Sr. } \\
\text { No. }\end{array}$ & Category & Frequency & Percentage \\
\hline 1. & $\begin{array}{c}\text { Low (below } 0.50 \\
\text { lakh) }\end{array}$ & 33 & 20.63 \\
\hline 2. & $\begin{array}{c}\text { Medium (0.51- } \\
1.00 \text { lakh) }\end{array}$ & 111 & 69.37 \\
\hline 3. & $\begin{array}{c}\text { High (above } \\
1.00 \text { lakh) }\end{array}$ & 16 & 10.00 \\
\hline & Total & 160 & 100 \\
\hline
\end{tabular}

It was found that majority $(69.37 \%)$ of the respondents had their annual income between Rs.0.51 to 1.00 lakh, followed by 20.63 per cent of respondents who had annual income below to Rs.0.50 lakh. Whereas 10.00 per cent of respondents were having their annual income above Rs.1.00 lakh. The results clearly indicated that majority of the respondents belonged to Rs.0.50 to 1.00 lakh annual income group.

\section{3-Marketing Behaviour}

Marketing behaviour refers to groundnut grower adoption about marketing conditions i.e. period of selling, to whom it is sold, which marketing channel have been used etc. Categorization of marketing behaviour has been done under following categories i.e. low, medium and high.

\begin{tabular}{|r|c|c|c|}
\hline $\begin{array}{r}\text { Sr. } \\
\text { No. }\end{array}$ & Category & Frequency & Percentage \\
\hline $\mathbf{1 .}$ & Low & 38 & 23.75 \\
\hline $\mathbf{2 .}$ & Medium & 96 & 60.00 \\
\hline $\mathbf{3 .}$ & High & 26 & 16.25 \\
\hline \multicolumn{2}{|c|}{ Total } & $\mathbf{1 6 0}$ & $\mathbf{1 0 0}$ \\
\hline
\end{tabular}

\section{Table -Distribution of respondents according to their marketing}

The data of Table 4.6 revealed that among all respondents, 60.00 per cent had medium market behaviour, followed by 23.75 per cent had low and 16.25 per cent respondents had high marketing behaviour. Thus it may concluded that the highest 60.00 per cent of farmers had medium proportion marketing behaviour.(Fig.6)

\section{Table - Distribution of respondents according to their marketing behaviour}

\begin{tabular}{|c|r|c|c|}
\hline Sr. No. & Marketing behaviour & Frequency & Percentage \\
\hline A. & Period of selling the produce & 47 & 29.38 \\
\hline 1. & Immediately after the harvest & 34 & 21.25 \\
\hline 2. & After one or two month of harvest by storing & 79 & $\mathbf{4}$ \\
\hline 3. & At the time of prices are favourable & $\mathbf{1 6 0}$ \\
\hline B. & Total & 68 & 42.50 \\
\hline 1. & To village level trader & 41 & 25.63 \\
\hline 2. & $\begin{array}{r}\text { To wholesalers through commission agent in the } \\
\text { regular market yard }\end{array}$ & & $\mathbf{1 0 0}$ \\
\hline
\end{tabular}


International Journal of Trend in Scientific Research and Development (IJTSRD) ISSN: 2456-6470

\begin{tabular}{|c|c|c|c|}
\hline 3. & To the trader through the Co-op Society. & 36 & 22.50 \\
\hline 4. & To the Govt. Agencies & 15 & 09.37 \\
\hline \multicolumn{2}{|c|}{ Total } & $\mathbf{1 6 0}$ & \\
\hline C. & $\begin{array}{c}\text { Which of the marketing channels would you } \\
\text { prefer? }\end{array}$ & 33 & 20.63 \\
\hline 1. & Directly to consumer & 29 & 18.12 \\
\hline 2. & To commission agent & 56 & 35.00 \\
\hline 3. & To whole seller & 24 & 15.00 \\
\hline 4. & To consumer enterprise & 18 & 11.25 \\
\hline 5. & To retailer & $\mathbf{1 6 0}$ & $\mathbf{1 0 0}$ \\
\hline
\end{tabular}

The data presented in the Table 4.7 showed the distribution of the respondents with respect to their frequency of marketing behaviour separately. The

Maximum number of the respondents $(49.37 \%)$ of the respondents had sold the produce at the time when prices were favourable, followed by 42.50 per cent had sold the produce to village level trader, 35.00 per cent of the respondents had used to whole seller as marketing channel.

\section{Extent of Adoption of the Farmers}

\section{Adoption regarding preparation of land}

Table 4.15 showed that majority of the respondents 76.25 per cent pertained medium adoption regarding preparation of land. Preparation of land is very important practice for the production. Farmers did their work according to their knowledge and adopted it.

\section{Adoption regarding time of sowing}

Table 4.15 showed that majority of the respondents 75.00 per cent pertained complete adoption regarding time of sowing. Farmers had complete knowledge about time of sowing and farmers completely adopted it.

\section{Adoption regarding use of improved varieties}

Table 4.15 showed that majority of the respondents 47.50 per cent pertained partial adoption regarding use of improved varieties. Farmers had medium knowledge about improved varieties, but they did not know the source of purchasing so their adoption level was low. High prices of improved variety were also a reason of low adoption.

\section{Adoption regarding seed treatment}

Table showed that majority of the respondents 59.38 per cent pertained partial adoption regarding seed treatment. Farmers do not know the benefits of seed treatment and hence it increased the cost of cultivation of the farmer.

\section{Adoption regarding seed rate}

Table showed that majority of the respondents 68.12 per cent pertained complete adoption regarding seed rate, because farmers had complete knowledge about it.

\section{Adoption regarding spacing}

Table showed that majority of the respondents 62.50 per cent pertained medium adoption regarding spacing. Proper sowing increased yield and farmers knew it, so the adopted it as per their knowledge.

\section{Adoption regarding intercropping}

Table showed that majority of the respondents 62.50 per cent pertained partial adoption regarding intercropping. Farmers did not adopt the intercropping because some harvesting and holding problem were faced by the farmers. 


\section{Adoption regarding use of manure}

Table showed that majority of the respondents 50.63 per cent pertained medium adoption regarding use of manure. Farmers knew the benefits of manure, so they used it.

\section{Adoption regarding fertiliser use}

Table showed that majority of the respondents 61.88 per cent pertained medium adoption regarding fertiliser use. Farmers had medium knowledge and they used fertilizer as per their knowledge.

\section{Adoption regarding water management}

Table showed that majority of the respondents 35.63 per cent pertained medium level of regarding water management. Farmers followed this practice as per the crop plant requirement.

\section{Adoption regarding weed management}

The perusal of data presented in Table showed that majority of the respondents 50.63 per cent pertained medium adoption regarding weed management. Farmers followed this practice as per their knowledge.

\section{Adoption regarding earthing up}

Table showed that majority of the respondents 68.12 per cent pertained partial adoption regarding earthing up. Farmers did not have knowledge about the earthing up and its benefits. This practice resulted in extra labour cost, so farmers did not adopt it.
Table showed that majority of the respondents 46.87 per cent pertained medium adoption regarding insect pest management. Farmers did insect pest management as per their knowledge.

\section{Adoption regarding diseases management}

Table showed that majority of the respondents 47.50 per cent pertained medium adoption regarding diseases management. Farmers had medium knowledge about it, so they adopted it at medium level.

\section{Adoption regarding harvesting practices}

Table showed that majority of the respondents 66.25 per cent pertained complete adoption regarding harvesting practices. Farmers did all their work according to their knowledge.

\section{Adoption regarding storage}

Table showed that majority of the respondents 61.25 per cent pertained partially adoption regarding storage. Farmers followed their knowledge and earned more profit from their production

A close examination of Table indicated that a considerable percentage (61.88 per cent) of respondents belonged to medium level of adoption, whereas 19.37 per cent and 18.75 per cent of farmers were in the low and high level categories of adoption respectively.

\section{Adoption regarding insect pest management}

\section{Relationship between extent of adoption and independent variables}

\begin{tabular}{|c|l|l|l|}
\hline $\begin{array}{l}\text { Sr. } \\
\text { No. }\end{array}$ & Characteristics & $\begin{array}{l}\text { Correlation coefficient } \\
(\mathbf{r})\end{array}$ & 't' value \\
\hline $\mathbf{1 .}$ & Area of groundnut & $0.797^{*}$ & 1.0055 \\
\hline $\mathbf{2 .}$ & Annual income & $0.134^{* *}$ & 1.7089 \\
\hline $\mathbf{3 .}$ & Marketing behaviour & $0.798^{*}$ & 1.0063 \\
\hline \multicolumn{2}{|c}{$\begin{array}{c}\mathbf{t} \text { Table value } \\
(\mathrm{N}-2) \text { d.f. }\end{array}$} & $\begin{array}{l}\mathbf{t}=\mathbf{1 . 6 5 4 5} \text { at } \mathbf{5} \% \\
\mathbf{t}=\mathbf{2 . 3 5 0 1} \text { at } \mathbf{1 \%}\end{array}$ \\
\hline
\end{tabular}

**Significant at 1 per cent level, *Significant at 5 per cent level, NS=non-significant

\section{1-Area of groundnut and adoption}

There was a positive and significant relationship between area of groundnut and adoption level of the farmers. Area of groundnut was related to adoption because farmer applied more recommended package of practices on his field and go more profit, which led to adoption. Hence the result is quite obvious. 


\section{2-Annual income and adoption}

There was a positive and significant relationship between annual income and adoption level of the bio fertiliser users. High annual income of farmers enhanced the purchasing power of them. Farmers took risk and use this technology. The findings show conformity with the finding of Kumar (2011).

\section{3- Marketing behaviour and adoption}

There was a positive and significant relationship between marketing behaviour and adoption level of the farmers. Groundnut has long storage capacity, so farmers stored it for a long time without heavy loss. Farmers sold their produce at high price in market, farmer used different marketing channels to sell the produce. Marketing behaviour was related to adoption. Hence it has led to adoption.

\section{CONCLUSION}

Majority of groundnut growers 60.00 per cent had medium level of marketing behaviour, indicated that characteristics namely area of groundnut, annual income and marketing behaviour, behaviour of respondents had positive and significant relationship with their adoption level

The present study also showed that lack of information about recommended groundnut production technology (45.00 per cent), so it is implicated that at least, a minimum number of demonstrations and field days around demonstrations are to be organized tehsil wise to convince farmers on the usefulness of recommended production technology

\section{REFERENCES}

1) Jyothi, M.S. and Anand, T.N. 2013. Knowledge and adopion of recommended technologies in groundnut cultivation among FLD and non FLD farmers. Mysore J. of Agril. Sci. 47(1): 171-175.

2) Kumar, A., Rathod, M.K. and Kalantri, L.B. 2012. Behaviour of farmers in adoption of recommended technology of soybean. Indian Res. J. of Ext. Edu., 2: 223-227.

3) Kumar, G.D.S. and Jain, V.K. 2011. Impact of adoption of winter-summer groundnut production technology on livelihood of farmers. J. Oilseeds Res., 28(2): 131-136.
4) Mugisha, J., Ogwal-o, R., Ekere, W. and Ekiyar, V. 2004. Adoption of IPMgroundnut production technology in Eastern Uganda. African Crop Sci. J. 12(4): 383-391.

5) Rogers, E.M., 1983. Diffusion of Innovation. The Free Press, New York.

6) Venkatta kumar, R. and Padmaiah, M. 2010. Adoption Behaviour of Oilseed Growers in India. Idian Res. J. Ext. Edu., 10(3): 75-83. 